\title{
Coming to My Senses
}

\author{
David James Savarese, BA
}

W HEN I WAS LITTLE, I once typed to my father-I use a text-to-voice synthesizer to communicate-"Autism sucks, but I see things that you don't see." The sky, for example, before it has become the sky. Or a barn before it has become a barn. Or even my own hand before it has become my hand. As in a painting by Seurat, the object appears as a million points of color, little flecks of something that do not need a name, and that hold my attention completely. Of course, I have learned to find the sky or barn or hand by making the points cohere, by giving them a name, but I regard the entire process as reductive and more than a little bit boring.

"In wilderness is the preservation of the world," Thoreau once wrote when wilderness still existed, when one could go to the woods to live deliberately. What would Thoreau do now with condos lining Walden Pond and the water too polluted to drink? He might wish that he were autistic - that wilderness lived in the eye or, rather, the brain. If he were autistic, "winged thoughts" would never "turn to poultry." Impressions would soar, not cluck in the farmyard pen. And he would "bathe [forever] in a golden flood.",

Am I too romantic? Perhaps. But remember, I also said that autism sucks. For the life of me, I cannot speak; my brain just won't allow it. Words linger in the cave of my mouth like a kid grounded in his room. I can say a few things. My adoptive father taught me how to say "stop," for instance-because I was attacked in foster care, he wanted me to be able to resist verbally if anything ever happened again — but it took months to learn. In general, my motor skills are quite poor. I cannot tie my shoes, and I scrape my teeth more than I brush them.

I also perseverate. That is a medical term-I use it in part ironically. It means that I engage in repetitive behavior, such as flapping my arms or touching lampposts with my elbows or making unusual noises. The word finds its origin in the notion of perseverance - as if it were possible, in my father's words, to persevere too long in something. Leave it to scientists to render a virtue pejorative. Thoreau perseverates on wildness. "I rejoice," he says, "that horses and steers have to be broken before they can be made the slaves of men, and that men themselves have some wild oats still left to sow before they become submissive members of society." 1 To resist the common mold one simply must be stubborn. In this respect, autism confers an advantage. I have oats enough for a hundred people.

The Diagnostic and Statistical Manual of Mental Disorders (or DSM) ${ }^{2}$ understands perseveration as a sign of impaired imagination, but some progressive scientists have recently proposed a theory that accords with my own experience and that of other autistic people. ${ }^{3}$ Because I take in a perpetual blizzard of detail and do not instinctively think in categories, the world seems much more new and complex than it does to nonautistic people. Thoreau speaks of the "gospel according to this moment,", and that gospel, no matter how beautiful, exhausts me. Not only exhausts me but also makes me anxious, for I cannot "relax," as my father explains, "into generalizations that do my seeing for me.", Nor can I predict what will come next since everything is so particular. And thus I compensate by turning experience into a villanelle, by using embodied morphing refrains to manage anxiety.

The theory suggests that autistic people excel at "local coherence" and nonautistic people at "global coherence.", 3 Unfortunately, it is often presented as an either/or phenomenon. You either do details or categories: indentations in bricks, say, or the bricks themselves. But many autistic people have learned to do both, and one thing that I appreciate about art, especially poetry, is that it values local coherence. For example, the way that alliteration weaves words together aurally in a line. It also values pattern detection, which seems to depend on the ability to move beneath the abstractions that organize the world and thereby find surprising connections, such as the indentations in bricks and the indentations in human faces. From such connections metaphor is born. Autistic people, research shows, possess superior pattern detection skills. ${ }^{5,6}$

Consider the following poem, which I wrote for a creative writing class, that makes a kind of carnival of local coherence. Although the words make sense, sense is not the point. The point is to watch the letters of the first and second lines of the first couplet become scrambled in the first and second lines of subsequent couplets. Freed from their customary subordination, the letters preen and prance, threatening to undermine the circus of meaning.

\footnotetext{
Ode to Iowa

Iowa soybeans in August-

what golden carpets!

I was being so augustgold hats, cars, pets.

O boy, Sean in August

thaws old carp.

I saw boys in gusts:

tag, hold, tarp.

Iowa, so be it, argh.

Hag noel, hark!
}

I love this poem: not so much the amber waves of grain as the grainy waves of amber. 
Toward the end of his essay "Walking," Thoreau remarks, "For my part, I feel that with regard to Nature I live a sort of border life, on the confines of a world into which I make occasional and transient forays only." ${ }^{1}$ He regrets not being a full-time "moss-trooper," and he says he "would gladly follow even a will-o'-the wisp through bogs and sloughs unimaginable, but no moon nor firefly has shown [him] the causeway to it." 1 I, too, live a sort of border life, but my forays into Seuratian Nature are anything but transient. In fact, the postman brings me my mail there. As I have said, I labor in the opposite direction-I struggle to find the cultivated gardens of categorical thought.

When I walk, I generally need to have a companion, but I do not exactly walk with that person. I tarry behind themsometimes 50 yards behind them. Thoreau says that in his walks he "would fain return to [his] senses." 1 Because I am in my senses most of the time-I tend to use posterior sensory regions of the brain to think-I am in danger of neglecting that most modern of predators: the automobile! I could notice the similar way that the light catches the windshield of a car and the skylight in my home in Iowa and end up crushed. The faint reminder of the person in front is enough to keep me from becoming entirely lost in patterned pulchritude. As my father once joked, he wants me around for at least another half century.

My peers at Oberlin have no doubt witnessed this spectacle. Picture me flapping my arms, making duck-like noises, greeting each lamppost with my elbows, sometimes sauntering, sometimes doing a jig, as I cross campus. The person in front repeatedly looks back like Orpheus to make sure I am there. I am usually carrying a backpack, a heavy backpack that helps me to locate my body in space. Autistic people experience both hyper- and hyposensitivity in each of their senses. If proprioception fails, I can use the backpack in the way that someone with a mobility impairment uses a cane. On really bad days, I will purposefully crash to the ground, landing on my butt to reboot the system. The thing to understand is that when I am walking, it is as if the world has found me, both worlds: the world of houses, trees, and sidewalks and the wilderness world of unlabeled impressions.

Although I completely understand Thoreau's wish to retreat from society, he perhaps does not appreciate the disabled person's wish to be included. To be in public is a privilege. Until the 1970 s, many states still had "ugly laws", on the books. Such laws forbade significantly disabled people from being in the public square. ${ }^{7}$ The idea was that disability was just too disturbing for nondisabled people. Perhaps it reminded them of life's merciless contingencies or of their own mortality. I was Oberlin College's first nonspeaking student with autism. As far as I know, only eight nonspeaking autistics have ever gotten a college degree. I was the first to live (with an aide) in a dorm. Walking on campus or in town was thus as thrilling — and as scary — as walking in nature was for Thoreau.

I chose Oberlin because it has a long history of inclusion. It accepted both the first female college student and the first African American female college student. For my previously mentioned creative writing class, I wrote a poem in honor of Mary Jane Patterson. In it I presented her literacy as akin to her parents' dash for freedom as slaves: both, I implied, involved a version of Thoreau's walking:
Underground Alphabet

If you hear the dogs, keep going. If you see the torches in the woods, keep going. If there's shouting after you, keep going. Don't ever stop. Keep going. If you want a taste of freedom, keep going.

- Harriet Tubman

A moves through the trees at night; $B$ covers her face; $C$ steals a canoe on the riverbank; D hides in a barn; $\mathrm{E}$ makes a run for it when cornered; F yells, "Freedom!" at the top of her lungs; G sobs when a fellow slave is caught; $\mathrm{H}$ fights off hunger; I sits in a classroom at Oberlin College, recalling her parents, Emeline Eliza and Henry Irving. They learned to read, she thinks, with their feet: striding frantically across the page. Called to the blackboard, Mary Jane Patterson, with perfect penmanship, writes the word future. Outside it's winter. Prejudice falls from the sky, blankets everything. ${ }^{8}$

I once told my father, "I look to Harriet for encouragement every day." I also look to Mary Jane.

In an essay that won an award, my father once depicted my high school inclusion experience as akin to the slave's experience of the Underground Railroad. ${ }^{9}$ The essay was less about how hard it had been to get into regular education than about how difficult I found it once I had gotten there. Not because I could not do the work but because the work sometimes disturbed me. Narratives such as The Adventures of Huckleberry Finn invite the reader to identify with a hero who faces brutal adversity. Because of the novel's comic tone, people forget that Huck is an abandoned child who was savagely beaten and nearly killed by his father. I faced similar circumstances in my own life, and the novel really activated my post-traumatic stress disorder. In my father's essay, I learn how to handle challenging material-to the extent that he shows me moving through the crowded halls of Grinnell High School longing for the safety of my American literature teacher's room.

What my father did not recognize was how daunting it was to be in public as a disabled person. That difficulty primed my anxiety, and it made reading a novel like Huck Finn doubly challenging. Just as Jim constantly worried about being captured by bounty hunters, so I worried about the dogged eyes of those who stared at me. "What's that retard doing here?" they would all but say-or, rather, bark, as ferociously as the bounty hunter's hounds. I have read that Tubman carried a rifle with her: as much to kill the bounty hunter as the slave should the latter experience a sudden failure of nerve. Tubman knew that the entire railroad would be put in jeopardy if the slave returned to her owner.

When I was very young, my only safe haven in foster care was with a proud African American couple who exposed me to black church, culture, and politics. Of course, my experience as the only visible nonspeaking student at my school is not the same as a slave's, but the fear of being identified as less than and "sent back" resonated with me. As a man, I know now that Tubman's peril far outweighed my own, but as a kid, she and Patterson most closely answered my need for mentors. That and my tendency to feel people's energy as if it were my own - to connect with others at a visceral levelamplified my identification with them.

Of course, no inclusion specialist has ever pointed a rifle at me, but still I can relate to sudden bouts of overwhelming fear. My first semester at Oberlin was a nightmare-not academically (I can write articles like nobody's business), but psychologically. My anxiety was so high and the barking orbs 
of my classmates were so loud that impulse superseded reason. In an anthropology lecture, I ran down to the front of the room and adjusted the pant legs of the professor: I simply did not like the way they fell across her shoes. Another time, I darted into the office of a physics professor and took a couple of books. I had never even met the man-the poor guy thought he had been robbed! But who steals a copy of $B e$ ginning Quantum Mechanics? When I am in the back of my head where our sensory regions are, with anxiety coursing like a swollen river through my veins, I am truly Thoreau's unbroken horse, anything but a domesticated chicken. All social awareness leaves me. I am impulse to the $n$th degree. (Even now, college degree in hand and fully employed, I can still succumb to the gawking of strangers as I make my way through crowded airports or speak to bobbing heads in an auditorium.)

But things got better at Oberlin, and I grew to love it. I saw a glimpse of that future love late in the first semester at a concert in the chapel. I remember getting out of my pew to dance - to the horror of most of the people around me. The music had commandeered my nerves, and I needed to thrash, needed to flap like a wet bird with my arms. Before I knew it, two black women in their 50s joined me, even taking my hands - their smiles were as wide as the Mississippi at Cairo (the place where Jim and Huck missed their turn). That night, when I went walking across campus, there was, as Thoreau would say, "so much more air and sunshine in [my] thoughts.',

\section{Author Disclosure Statement}

No competing financial interests exist.

\section{References}

1. Thoreau HD. Walking. Atl. 1862. https://www.theatlantic.com/ magazine/archive/1862/06/walking/304674 (accessed April 30, 2017).

2. American Psychiatric Association. Diagnostic and Statistical Manual of Mental Disorders, 5th Edition. Arlington, Virginia: American Psychiatric Publishing; 2013.

3. Happé F, Frith U. The weak coherence account: Detailfocused cognitive style in autism spectrum disorders. J Autism Dev Disord. 2006;36(1):5-25.

4. Savarese RJ. Toward a postcolonial neurology: Autism, tito mukhopadhyay, and a new geo-poetics of the body. J Lit Cult Disabil Stud. 2010:273-290.

5. Caron MJ, Mottron L, Rainville C, Chouinard S. Do high functioning persons with autism present superior spatial abilities? Neuropsychologia. 2004;42(4):467-481.

6. Mottron L, Dawson M, Soulières I, Hubert B, Burack J. Enhanced perceptual functioning in autism: An update, and eight principles of autistic perception. J Autism Dev Disord. 2006;36(1):27-43.

7. Schweik SM. The Ugly Laws: Disability in Public. New York: NYU Press; 2010.

8. Deej RR. 2017. https://www.deejmovie.com/about (accessed April 30, 2017).

9. Savarese RJ. River of words, raft of our conjoined neurologies. Fourth Genre. 2012;14(1). http://www.ralphsavarese.com/wpcontent/uploads/2012/05/River-of-Words.pdf (accessed April $30,2017)$.

Address correspondence to: David James Savarese, BA

E-mail: dj.savarese@gmail.com 